\title{
Developmental Changes in the Acute Ethanol Sensitivity of Glutamatergic and GABAergic Transmission in the BNST
}

\author{
T.A. Wills ${ }^{1,2}$, T.L. Kash ${ }^{4,5}$, and D.G. Winder ${ }^{1,2,3}$ \\ ${ }^{1}$ Department of Molecular Physiology \& Biophysics, Vanderbilt University School of Medicine \\ ${ }^{2}$ Center for Molecular Neuroscience, Vanderbilt University School of Medicine \\ 3J.F. Kennedy Center for Research on Human Development, Vanderbilt University School of \\ Medicine \\ ${ }^{4}$ Department of Pharmacology, University of North Carolina at Chapel Hill \\ ${ }^{5}$ Bowles Center for Alcohol Studies, University of North Carolina at Chapel Hill
}

\section{Abstract}

Glutamatergic and GABAergic transmission undergo significant changes during adolescence. Receptors for both of these transmitters (N-methyl-D-aspartate, NMDAR, and $\mathrm{GABA}_{\mathrm{A}}$ ) are known to be key targets for the acute effects of ethanol in adults. The current study set out to investigate the acute effects of ethanol on both NMDAR-mediated excitatory transmission and GABAergic inhibitory transmission within the bed nucleus of the stria terminalis (BNST) across age. The BNST is an area of the brain implicated in the negative reinforcing properties associated with alcohol dependence, and the BNST plays a critical role in stress-induced relapse. Therefore, assessing the developmental regulation of ethanol sensitivity in this key brain region is important to understanding the progression of ethanol dependence. To do this, whole-cell recordings of isolated NMDAR-evoked excitatory postsynaptic currents (eEPSCs) or evoked GABAergic inhibitory postsynaptic currents (eIPSCs) were performed on BNST neurons in slices from 4- or 8week-old male C57BL/6J mice. Ethanol (50 mм) produced greater inhibition of NMDAR-eEPSCs in adolescent mice than in adult mice. This enhanced sensitivity in adolescence was not a result of shifts in function of the B subunit of NMDARs (GluN2B), measured by Ro25-6981 inhibition and decay kinetics measured across age. Adolescent mice also exhibited greater ethanol sensitivity of GABAergic transmission, as ethanol $(50 \mathrm{~mm})$ enhanced eIPSCs in the BNST of adolescent but not adult mice. Collectively, this work illustrates that a moderate dose of ethanol produces greater inhibition of transmission in the BNST (through greater excitatory inhibition and enhancement of inhibitory transmission) in adolescents compared to adults. Given the role of the BNST in alcohol dependence, these developmental changes in acute ethanol sensitivity could accelerate neuroadaptations that result from chronic ethanol use during the critical period of adolescence.

(C) 2013 Elsevier Inc. All rights reserved.

Corresponding Author: Danny G. Winder, Ph.D., Department of Molecular Physiology \& Biophysics, 23rd and Pierce Ave S, Room 754, RRB, Vanderbilt University School of Medicine, Nashville, TN 37232-0615, Phone: +1 615322 1144, Fax: +1 615343 0490, danny.winder@vanderbilt.edu.

Publisher's Disclaimer: This is a PDF file of an unedited manuscript that has been accepted for publication. As a service to our customers we are providing this early version of the manuscript. The manuscript will undergo copyediting, typesetting, and review of the resulting proof before it is published in its final citable form. Please note that during the production process errors may be discovered which could affect the content, and all legal disclaimers that apply to the journal pertain. 


\section{Keywords}

adolescent; NMDA receptor; bed nucleus of the stria terminalis (BNST); GABA; GluN2B

\section{Introduction}

Adolescence is known to be a time of increased risk-taking behaviors, including alcohol use. This alcohol use is not only experimental but also consists of high levels of binge drinking (5 or more drinks in one occasion; Rohde et al., 1996). This adolescent alcohol exposure is one of the strongest predictors for future alcohol dependence (Grant, 1998) and produces a more rapid dependency course (time between initial use and dependence; Clark et al., 1998). Therefore, identifying the neurobiological underpinnings of these age-related differences is important to understanding the development of alcohol dependence and understanding how treatments might be able to intercede in this process.

Numerous studies using rodent models have shown that adolescent and adult behavioral responses to acute ethanol are distinct. For example, adolescents have lower sensitivity to the sedative (Little et al., 1996; Silveri \& Spear, 1998), hypothermic (Silveri \& Spear, 2000), conditioned taste aversion (Anderson et al., 2010; Holstein et al., 2011; SchrammSapyta et al., 2010), and motor impairing (White et al., 2002) effects of alcohol, but greater sensitivity to ethanol-induced memory impairment and social facilitation (Markwiese et al., 1998; Varlinskaya \& Spear, 2002, 2006).

The key to these age-related effects likely arises from maturational changes in the brain that occur during adolescence. The transition from adolescence to adulthood is accompanied by a peak in grey matter volume that declines into adulthood (Giedd, 2004; Giedd et al., 1999). This reduction is in part a result of synaptic pruning of glutamatergic synapses, particularly in the cortex and hippocampus (Andersen \& Teicher, 2004; Andersen et al., 2000; Giedd et al., 1999; Huttenlocher, 1984; Insel et al., 1990; Zecevic et al., 1989). Specifically in these regions, there is a substantial decline in glutamatergic NMDA receptors (NMDARs; Insel et al., 1990) and a shift in NMDAR subunit composition, with enhancement of GluN2A over GluN2B (Quinlan et al., 1999; Sheng et al., 1994; Sobczyk et al., 2005; Williams et al., 1993; Yashiro \& Philpot, 2008). While this subunit shift is prevalent in the cortex, hippocampus, and lateral amygdala, the central nucleus of the amygdala (CeA) seems resistant and retains significant GluN2B levels into adulthood (Lopez de Armentia \& Sah, 2003). These data illustrate regional differences in the developmental maturation of glutamatergic synapses and highlight the need for refined characterization of these changes in ethanol-sensitive brain regions (e.g. the BNST). These changes in excitatory transmission occur in conjunction with an overall increase in GABAergic tone resulting from a developmental increase in $\mathrm{GABA}_{\mathrm{A}}$ receptors in numerous brain regions (Behringer et al., 1996; Fleming et al., 2007; Moy et al., 1998; Xia and Haddad, 1992). These developmental changes in both GABAergic and glutamatergic transmission are thus candidates to underlie age-related differences in the behavioral effects of alcohol.

One of the primary effects of acute ethanol exposure is inhibition of NMDAR-mediated transmission (Dildy \& Leslie, 1989; Hoffman et al., 1989; Lovinger et al., 1989). In the hippocampus and posterior cingulate cortex of adolescents, this inhibition of NMDAR transmission by acute ethanol was more robust than in their adult counterparts ( $\mathrm{Li}$ et al., 2002; Swartzwelder et al., 1995b). Further, long-term potentiation (LTP), a form of NMDAR-dependent hippocampal plasticity, showed enhanced disruption by ethanol exposure in adolescents (Pyapali et al., 1999; Swartzwelder et al., 1995a). This enhanced 
effect of acute ethanol on NMDAR transmission and LTP in adolescents is likely a result of developmental changes in NMDAR levels and subunit composition.

Another system vulnerable to ethanol in adults is GABAergic transmission. Similar to the ethanol sensitivity of NMDARs, much of the research on the sensitivity of GABAergic transmission to alcohol has been performed in the hippocampus. In this region, $\mathrm{GABA}_{\mathrm{A}^{-}}$ mediated evoked inhibitory post-synaptic currents (eIPSCs) had greater ethanol-induced enhancement in adults compared to adolescents ( $\mathrm{Li}$ et al., 2003). This age-related difference was produced by greater ethanol-induced augmentation of $\mathrm{I}_{\mathrm{h}}$ current in adults, which results in an enhancement of interneuron excitability ( $\mathrm{Li}$ et al., 2006; Yan et al., 2010). Conversely, other interneurons in the hippocampus were shown to have greater enhancement of inhibitory tonic current by ethanol in adolescents compared to adults (Yan et al., 2010). This age-related difference in response of tonic GABAergic current to ethanol was later found to be at least partially mediated through developmental changes in GABA transporter (Fleming et al., 2011). These disparate findings in hippocampal neurons, with adults being more ethanol sensitive in one instance and less in another, were found to be restricted to different subclasses of GABAergic interneurons, thus highlighting the complexity of ethanol effects.

In the current study, we set out to investigate the age-dependent effects of ethanol on both NMDAR-mediated excitatory transmission and GABAergic inhibitory transmission within the bed nucleus of the stria terminalis (BNST). The BNST is an area of the brain associated with the negative reinforcing properties of drug/alcohol dependence, and has been shown in numerous studies to be critical for expression of stress-induced reinstatement of drugseeking behavior (Briand et al., 2010; Buffalari \& See, 2011; Erb et al., 2001; Erb \& Stewart, 1999; Leri et al., 2002; Wang et al., 2006). In the adult BNST, the acute effects of ethanol are dependent on the GluN2B subunit of the NMDAR (Wills et al., 2012). However, the developmental regulation of this subunit and the effects of ethanol in this region have not been evaluated. Therefore, determining the developmental regulation of ethanol sensitivity in this brain region is important to understanding the progression of ethanol dependence.

\section{Materials and methods}

\section{Subjects}

Male C57BL/6J (4 weeks old, postnatal days 28-34; or 8 weeks old, postnatal days 56-62; Jackson Laboratories, Bar Harbor, ME) were housed in groups of five. Food and water were available ad libitum. All procedures were approved by the Animal Care and Use Committee at Vanderbilt University.

\section{Procedures}

Slice preparation-Mice were transported from the animal colony to the laboratory and placed in sound-attenuated cubicles for 1 hour. They were then decapitated under isoflurane anesthesia. The brains were quickly removed and placed in ice-cold sucrose artificial cerebrospinal fluid (ACSF) (in mм: 194 sucrose, $20 \mathrm{NaCl}, 4.4 \mathrm{KCl}, 2 \mathrm{CaCl}_{2}, 1 \mathrm{MgCl}_{2}, 1.2$ $\mathrm{NaH}_{2} \mathrm{PO}_{4}, 10.0$ glucose, and $26.0 \mathrm{NaHCO}_{3}$ ), saturated with $95 \% \mathrm{O}_{2} / 5 \% \mathrm{CO}_{2}$. Slices $300 \mu \mathrm{m}$ thick were prepared using a Tissue Slicer (Leica). Slices containing ventral BNST (vBNST; bregma, $0.26-0.02 \mathrm{~mm}$ ) were selected using the internal capsule, anterior commissure, and stria terminalis as landmarks.

Whole-cell recordings-After dissection, slices were transferred to a holding chamber containing heated $\left(29^{\circ} \mathrm{C}\right.$ ), oxygenated $\left(95 \% \mathrm{O}_{2} / 5 \% \mathrm{CO}_{2}\right)$ ACSF (in mм: $124 \mathrm{NaCl}, 4.4$ $\mathrm{KCl}, 2 \mathrm{CaCl}_{2}, 1.2 \mathrm{MgSO}_{4}, 1 \mathrm{NaH}_{2} \mathrm{PO}_{4}, 10.0$ glucose, and $26.0 \mathrm{NaHCO}_{3} ; \mathrm{pH} 7.2-7.4 ; 290$ $310 \mathrm{mOsm}$ ). Recording electrodes (3-6 M $\Omega$ ) were pulled on a Flaming-Brown Micropipette 
Puller (Sutter Instruments) using thin-walled borosilicate glass capillaries. Excitatory postsynaptic currents (eEPSCs) were evoked by local fiber stimulation with bipolar nichrome electrodes. Electrical stimulation (5-25 V with a 100-150 $\mu$ sec duration) was applied at $0.0167 \mathrm{~Hz}$. An electrical stimulation intensity that evoked a $100-300 \mathrm{pA}$ NMDAR-EPSC was used in these experiments. Recording electrodes were filled with a solution containing in $\mathrm{m}_{\mathrm{M}}$ ): $117 \mathrm{Cs}^{+}$-gluconate, 20 HEPES, 0.4 EGTA, 5 TEA, $2 \mathrm{MgCl}_{2}, 4$ ATP, 0.3 GTP, $\mathrm{pH}=7$; 285-290 mOsm). NMDAR EPSCs were isolated by adding $25 \mu \mathrm{M}$ picrotoxin and $10 \mu \mathrm{M}$ NBQX, and recording at a holding potential of $+40 \mathrm{mV}$ in normal ACSF at a fluid exchange rate of $2 \mathrm{~mL} / \mathrm{min}$. Inhibitory post-synaptic current (eIPSC) recordings were isolated by applying kynurenic acid $\left(3 \mathrm{~m}_{\mathrm{M}}\right)$ and recording at a holding potential of $-70 \mathrm{mV}$. Signals were acquired via a Multiclamp 700B amplifier (Axon Instruments), and digitized and analyzed via pClamp 10.2 software (Axon Instruments). Input resistance, holding current, and series resistance were all monitored continuously throughout the duration of experiments. Experiments in which changes in series resistance were greater than $20 \%$ were not included in the data analysis. Experiments were analyzed by measuring peak amplitude of the synaptic response, which was then normalized to the baseline period.

Weighted tau $\left(T_{\omega}\right)$ was calculated by fitting NMDA-eEPSC decays using Clampfit 10.2 (Axon Instruments) from averaged traces obtained 5 min prior to drug ( $50 \mathrm{~m} \mathrm{M}$ ethanol) application and 5 min after washout (minimum 10-15 minutes of washout). The decay phase of currents was fitted using a simplex algorithm for least-squares exponential-fitting routine with a double exponential equation, where Ix is the peak current amplitude and Tx is the corresponding decay time constant. To allow for easier comparison of decay times between experimental conditions, the 2 decay time components were combined into a weighted time constant.

\section{Drug Treatments}

Stable baselines of at least 5 min were recorded before drug application: 10 min for ethanol $(10,25$, or $50 \mathrm{~mm}$ ) and $10 \mathrm{~min}$ for Ro25-9681 hydrochloride (Ascent Scientific; $2 \mu \mathrm{M}$ ). NBQX hydrochloride (Ascent Scientific), picrotoxin (Tocris Bioscience), and kynurenic acid (Sigma-Aldrich), when used, were applied for the duration of the experiment.

\section{Statistical Analysis}

Analyses of the effects of Ro25-6981 and 50 mм ethanol on NMDAR-EPSCs were performed with unpaired $t$ tests. Analyses of the effects of $50 \mathrm{~m}_{\mathrm{M}}$ ethanol on IPSCs were performed with an unpaired $t$ test using a Welch correction due to unequal variance between groups. A 1-way ANOVA was performed on the ethanol dose response on NMDAR-EPSCs in 4-week-old pups. All analyses were made by calculating the percent change from baseline (averaged $5 \mathrm{~min}$ before drug application) to peak drug effect (first $5 \mathrm{~min}$ of washout). This peak drug effect occurs during the washout phase because it takes 6-8 minutes for solutions to equilibrate to a steady state concentration in the slice chamber.

The $N$ for these data analyses is a reflection of the number of slices used per group. These slices were collected from at least 4 mice per group in all cases. The specific $n$ for each of the treatment groups were as follows. Four-week-old mice, NMDA EPSCs: $10 \mathrm{~m}_{\mathrm{M}}$ ethanol $(n=4) ; 25$ тм ethanol $(n=4) ; 50$ тм ethanol $(n=7)$; Ro25-6981 $(n=6)$. Four-week-old mice, IPSCs: $50 \mathrm{~m}_{\mathrm{м}}$ ethanol $(n=7)$. Eight-week-old mice, NMDA EPSCs: $50 \mathrm{~m}_{\mathrm{M}}$ ethanol ( $n$ =7); Ro25-6981 $(n=6)$. Eight-week-old mice, IPSCs: 50 mм ethanol $(n=5)$. 


\section{Results}

\section{Effects of acute ethanol on NMDAR transmission in the BNST}

Acute ethanol application produces a dose-dependent inhibition of NMDAR-EPSC amplitude in vBNST neurons of adult C57BL/6J male mice (Kash et al., 2008). To determine potential age-related differences in acute ethanol sensitivity within the vBNST, an intermediate ethanol dose $(50 \mathrm{~mm})$ was chosen from these previous findings in adult mice (Kash et al., 2008). Whole-cell recordings were made from neurons in the vBNST in coronal brain slices from 4- or 8-week-old male C57BL/6J mice. We selected smaller cell somas with large input resistance, as these characteristics have been previously ascribed to projection neurons (Dumont \& Williams, 2004; Kash et al., 2008). NMDAR-EPSCs were generated by local afferent stimulation at a holding potential of $+40 \mathrm{mV}$ in the presence of picrotoxin and NBQX. Basal peak amplitude of NMDAR-EPSCs was not significantly different between 4 - and 8-week-old mice $(\mathrm{t}[13]=0.6443 ; p=$ N.S.; 8-week-old mice $=$ $164.5 \mathrm{pA} \pm 35.57$; 4-week-old mice $=133.1 \mathrm{pA} \pm 26)$. Ethanol $(50 \mathrm{~mm})$ produced an inhibition of NMDAR-EPSC peak amplitude in 8-week-old mice, as was previously shown (Kash et al., 2008). This same inhibition of peak amplitude, however, was larger in 4-weekold mice $(\mathrm{t}[17]=3.849 ; p<0.005$; Figs. $1 \mathrm{~A} \& \mathrm{C})$. This age-related difference was also found in the inhibition of NMDAR-EPSC area $(\mathrm{t}[17]=2.152 ; p<0.05$; Figs. 1D \& E). These age-related differences in NMDAR-EPSCs were also apparent in representative traces from 4- and 8-week-old mice before and after ethanol application (Fig. 1B). Dose-response experiments in 4-week-old mice revealed a significant effect of ethanol dose $(10,25$, or 50 $\left.\mathrm{m}_{\mathrm{M}}\right)$ on NMDAR-EPSC peak $\left(F_{(2,21)}=4.757 ; p=0.021\right.$; Fig. $\left.2 \mathrm{~A}, \mathrm{~B}\right)$ but not on NMDAREPSC area $\left(F_{(2,21)}=1.637 ; p=\right.$ N.S.; Fig. 2A,C). In NMDAR-EPSC peaks, the percent of baseline values for $10 \mathrm{~m}_{\mathrm{M}}$ ethanol and $50 \mathrm{~m}_{\mathrm{M}}$ ethanol were significantly different, with $10 \mathrm{~m}_{\mathrm{M}}$ ethanol producing no appreciable effect. Collectively, these measurements demonstrate that ethanol inhibition at NMDARs is more robust in 4-week-old compared to 8-week-old mice.

An age-related difference in ethanol sensitivity could reflect developmental regulation of NMDAR subunits. Previous work has illustrated that ethanol sensitivity in the BNST is dependent on the GluN2B subunit (Wills et al., 2012), and expression of this subunit is known to be developmentally regulated in other brain regions. Since subunit composition is a determinant of the decay kinetics of NMDAR currents, weighted Tau $\left(T_{\omega}\right)$ measurements were taken from NMDAR-isolated eEPSCs before and after ethanol inhibition in 4- and 8week-old mice. There was no age-related difference in $\mathrm{T}_{\omega}$ before $(\mathrm{t}[17]=1.002 ; p=$ N.S.; 8 week-old mice $=130.6 \pm 14.23$; 4 -week-old mice $=106.4 \pm 14.18$ ) or after ethanol application $(\mathrm{t}[17]=0.194 ; p=$ N.S.; 8 -week-old mice $=102.7 \pm 14.25 ; 4$-week-old mice $=$ $108.6 \pm 25.59)$. A secondary assessment of subunit composition was performed evaluating the amount of inhibition by Ro25-6981 ( $2 \mu \mathrm{M}$; selective GluN2B antagonist) on NMDAREPSCs in 4- and 8-week-old mice. There were no differences in the magnitude of Ro25-6981 inhibition on NMDAR-EPSC peak amplitude (t[14] = 1.477; $p=$ N.S.; Fig. 3A) or NMDAR-EPSC area between ages ( $\mathrm{t}[14]=0.1597 ; p=\mathrm{N}$.S.; Fig. 3B). These findings suggest that GluN2B composition may be similar between 4- and 8-week-old mice in the vBNST, despite age-related differences in ethanol sensitivity.

\section{Effects of acute ethanol on GABA transmission in the BNST}

In conjunction with this excitatory transmission, there is also substantial inhibitory transmission in the vBNST. Previous work in adult mice found that $100 \mathrm{~m}_{\mathrm{M}}$ acute ethanol had no effect on IPSCs in the BNST, but this concentration was more than sufficient to inhibit NMDAR-EPSCs (Weitlauf et al., 2004). In the current experiments, the effect of 50 $\mathrm{m}_{\mathrm{M}}$ ethanol (shown to produce age-related differences on NMDAR transmission) on IPSCs was evaluated in neurons within the vBNST. Ethanol $(50 \mathrm{~mm})$ produced no significant age- 
related difference in eIPSC peak amplitude (t[11] $=1.343 ; p=$ N.S.; Figs. 4A \& C), although there was a trend for ethanol-induced enhancement of eIPSCs in 4-week-old mice. However, when eIPSC area was evaluated, there was an age-related difference in ethanol sensitivity (t $[12]=2.213 ; p<0.05$; Figs. $4 \mathrm{D} \& \mathrm{E}$ ). This difference was a consequence of ethanol-induced enhancement of eIPSCs in 4-week-old mice with no ethanol-induced change in eIPSCs in 8-week-old mice (see representative traces before and after $50 \mathrm{~mm}$ ethanol in Fig. 4B).

\section{Discussion}

These studies demonstrate clear developmental differences in the effects of ethanol on NMDAR-mediated excitatory transmission and GABAergic inhibitory transmission. Adolescent mice were more sensitive to ethanol-mediated inhibition of NMDAR transmission and more sensitive to ethanol-mediated enhancement of inhibitory transmission. The culmination of these effects illustrates that ethanol produces greater inhibition of neural transmission in the BNST in 4-week-old mice than the same ethanol concentration in 8-week-old mice. Further, it is important to note that, while the ethanol concentrations used in these studies are somewhat high (translates into approximately 230 $\mathrm{mg} \%$ ), they are well within the range of blood ethanol concentrations (BECs) achieved by drinking adolescents. One of the potential reasons for the greater preponderance of these higher BECs among adolescents is that they are less susceptible to sedative properties of ethanol than adults are (Little et al., 1996; Silveri \& Spear, 1998). Additionally, lower concentrations $\left(25 \mathrm{~m}_{\mathrm{M}}\right)$ were also effective in inhibiting NMDAR-EPCSs in adolescents, as has been previously demonstrated in adults (Kash et al., 2008).

Age-related differences in NMDAR ethanol sensitivity have been found in other brain regions (Li et al., 2002; Swartzwelder et al., 1995b), with adolescents displaying enhanced ethanol-induced inhibition on NMDARs. A number of factors could contribute to these agerelated differences in ethanol sensitivity: subunit composition, co-agonist activation, $\mathrm{Mg}$ blockade, phosphorylation states, intracellular signaling cascades, etc. Any of these factors could account for the disparate actions of ethanol on NMDARs across age.

Developmental changes in NMDAR subunit composition are one possible explanation for age-dependent differences in ethanol sensitivity. As was discussed above, there is an overall decline in NMDARs and a shift in subunit composition from predominantly GluN2B to GluN2A in many regions (e.g. hippocampus and cortex). GluN2A and GluN2B (with the obligate GluN1 subunit) are the primary NMDAR subunits expressed in the forebrain and confer many of the receptor properties. NMDAR composition (especially GluN2B vs. GluN2A) confers many of the receptor properties, such as decay time, localization, signaling, and conductance. Further, previous work in our laboratory has shown that the acute inhibitory effects of acute ethanol on the NMDAR are GluN2B-dependent (Wills et al., 2012). We assessed the developmental shift in subunit composition by evaluating the amount of Ro25-6981 (GluN2B antagonist) inhibition and basal age-related differences in decay kinetics (with $\mathrm{T}_{\omega}$ ). Our results found no age-related difference in inhibition by Ro25-6981 or basal decay kinetics. These results suggest that the BNST does not undergo the same developmental shift to GluN2A-containing NMDARs found in many brain regions (hippocampus, cortex, striatum, lateral amygdala, and cerebellum). This lack of a developmental shift has also been found in the CeA (Lopez de Armentia \& Sah, 2003). While our data suggest that a large-scale shift from GluN2B to GluN2A does not occur in the BNST, it is possible that changes in subunit composition between NMDARs containing 2 subunits types (e.g., two GluN2B-two GluN1) and those containing 3 subunit types (e.g., GluN2A-GluN2B-two GluN1) NMDARs might occur developmentally. Ro inhibition may be unable to detect such developmental shifts since the efficacy of this antagonist on 
heterotrimeric NMDARs is not well understood. Another possibility is that subunit composition is conserved across these developmental stages and that ethanol-related differences are a response of divergent signaling, total NMDAR number, or changes in receptor phosphorylation. Several studies have found phosphorylation sites on GluN1 (expressed with GluN2A) that alter acute ethanol sensitivity (Honse et al., 2004; Ren et al., 2003; Ren et al., 2007; Ronald et al., 2001; Smothers \& Woodward, 2006). Further, various kinases (e.g. H-Ras, Syc, Fyn, STEP, DARPP-32) are known to alter the phosphorylation/ dephosphorylation of the NMDAR subunit and in turn influence NMDAR sensitivity to ethanol (Alvestad et al., 2003; Hardy et al., 1999; Hicklin et al., 2011; Maldve et al., 2002; Suvarna et al., 2005; Yaka et al., 2003a, 2003b). Therefore, developmental changes in NMDAR phosphorylation states and kinase activity could also account for these age-related effects in the BNST and will need to be investigated in future studies.

In conjunction with these age-related changes in NMDAR-mediated transmission, ethanol sensitivity differences were also found for inhibitory transmission in the BNST. In these studies, there was an enhancement of IPSC by acute ethanol $(50 \mathrm{~m})$ in slices from adolescent mice, whereas no effect of ethanol was seen in their adult counterparts. These changes in ethanol sensitivity are potentially a consequence of developmental changes in GABA receptor expression and/or subunit composition. $\mathrm{GABA}_{\mathrm{A}}$ has been shown to steadily increase in expression into adulthood (Behringer et al., 1996; Xia \& Haddad, 1992).

However, certain brain regions show distinct rates of $\mathrm{GABA}_{\mathrm{A}}$ receptor expression (measured by zolpidem binding) during adolescence (Moy et al., 1998). These overall $\mathrm{GABA}_{\mathrm{A}}$ changes are also accompanied with developmental shifts in subunit composition with increases in the $\delta$ subunit, and general decline with age in $\alpha 1, \alpha 3$, and $\alpha 5$ subunits (Laurie et al., 1992; Yu et al., 2006). Developmental ethanol sensitivity has been most extensively characterized in the hippocampus where work has shown adolescents to be either more or less sensitive to the effects of acute ethanol depending on the type of GABAergic transmission being evaluated (discussed above). Our current work did not isolate specific GABA subunits so it is unclear if the acute ethanol mechanisms at work in the BNST are similar to those seen in the hippocampus. Another potential mechanism for enhanced GABA transmission by acute ethanol comes from work in the adult CeA, another subregion of the extended amygdala. In this region, enhancement of GABAergic transmission by acute ethanol occurs via enhancement of presynaptic GABA release via CRF receptor signaling through $\mathrm{PKC}_{\epsilon}$ (Bajo et al., 2008; Roberto et al., 2004). Further studies will be necessary to determine the precise mechanisms underlying these developmental changes in ethanol sensitivity in the BNST.

In sum, these developmental changes in ethanol sensitivity demonstrate that ethanol exposure during adolescence produces a larger inhibition of transmission (through greater excitatory inhibition and enhancement of inhibitory transmission) in the BNST than the same amount of ethanol in adults. This suggests that lower amounts of ethanol would be required to affect BNST-related behaviors and neuroadaptions that occur during chronic ethanol use. Given the role of the BNST in negative effect and relapse, it is likely that this increased sensitivity to ethanol in the BNST during adolescence could accelerate the progression of ethanol dependence. While these studies provide intriguing initial findings about developmental differences in the BNST, future studies are needed to evaluate later adolescent periods, more chronic ethanol treatments, and the mechanisms for these changes in ethanol sensitivity. 


\section{References}

Alvestad RM, Grosshans DR, Coultrap SJ, Nakazawa T, Yamamoto T, Browning MD. Tyrosine dephosphorylation and ethanol inhibition of N-Methyl-D-aspartate receptor function. The Journal of Biological Chemistry. 2003; 278:11020-11025. [PubMed: 12536146]

Andersen SL, Teicher MH. Delayed effects of early stress on hippocampal development. Neuropsychopharmacology. 2004; 29:1988-1993. [PubMed: 15316569]

Andersen SL, Thompson AT, Rutstein M, Hostetter JC, Teicher MH. Dopamine receptor pruning in prefrontal cortex during the periadolescent period in rats. Synapse. 2000; 37:167-169. [PubMed: 10881038]

Anderson RI, Varlinskaya EI, Spear LP. Ethanol-induced conditioned taste aversion in male spraguedawley rats: impact of age and stress. Alcoholism: Clinical and Experimental Research. 2010; 34:2106-2115.

Bajo M, Cruz MT, Siggins GR, Messing R, Roberto M. Protein kinase C epsilon mediation of CRFand ethanol-induced GABA release in central amygdala. Proceedings of the National Academy of Sciences of the United States of America. 2008; 105:8410-8415. [PubMed: 18541912]

Behringer KA, Gault LM, Siegel RE. Differential regulation of GABA A receptor subunit mRNAs in rat cerebellar granule neurons: importance of environmental cues. Journal of Neurochemistry. 1996; 66:1347-1353. [PubMed: 8627285]

Briand LA, Vassoler FM, Pierce RC, Valentino RJ, Blendy JA. Ventral tegmental afferents in stressinduced reinstatement: the role of cAMP response element-binding protein. The Journal of Neuroscience. 2010; 30:16149-16159. [PubMed: 21123561]

Buffalari DM, See RE. Inactivation of the bed nucleus of the stria terminalis in an animal model of relapse: effects on conditioned cue-induced reinstatement and its enhancement by yohimbine. Psychopharmacology (Berl). 2011; 213:19-27. [PubMed: 20827461]

Clark DB, Kirisci L, Tarter RE. Adolescent versus adult onset and the development of substance use disorders in males. Drug and Alcohol Dependency. 1998; 49:115-121.

Dildy JE, Leslie SW. Ethanol inhibits NMDA-induced increases in free intracellular Ca2+ in dissociated brain cells. Brain Research. 1989; 499:383-387. [PubMed: 2572303]

Dumont EC, Williams JT. Noradrenaline triggers GABAA inhibition of bed nucleus of the stria terminalis neurons projecting to the ventral tegmental area. The Journal of Neuroscience. 2004; 24:8198-8204. [PubMed: 15385602]

Erb S, Salmaso N, Rodaros D, Stewart J. A role for the CRF-containing pathway from central nucleus of the amygdala to bed nucleus of the stria terminalis in the stress-induced reinstatement of cocaine seeking in rats. Psychopharmacology (Berl). 2001; 158:360-365. [PubMed: 11797056]

Erb S, Stewart J. A role for the bed nucleus of the stria terminalis, but not the amygdala, in the effects of corticotropin-releasing factor on stress-induced reinstatement of cocaine seeking. The Journal of Neuroscience. 1999; 19:RC35. [PubMed: 10516337]

Fleming RL, Acheson SK, Moore SD, Wilson WA, Swartzwelder HS. GABA transport modulates the ethanol sensitivity of tonic inhibition in the rat dentate gyrus. Alcohol. 2011; 45:577-583. [PubMed: 21600727]

Fleming RL, Wilson WA, Swartzwelder HS. Magnitude and ethanol sensitivity of tonic GABAA receptor-mediated inhibition in dentate gyrus changes from adolescence to adulthood. Journal of Neurophysiology. 2007; 97:3806-3811. [PubMed: 17376852]

Giedd JN. Structural magnetic resonance imaging of the adolescent brain. Annals of the New York Academy of Sciences. 2004; 1021:77-85. [PubMed: 15251877]

Giedd JN, Jeffries NO, Blumenthal J, Castellanos FX, Vaituzis AC, Fernandez T, Hamburger SD, Liu $\mathrm{H}$, Nelson J, Bedwell J, et al. Childhood-onset schizophrenia: progressive brain changes during adolescence. Biological Psychiatry. 1999; 46:892-898. [PubMed: 10509172]

Grant BF. The impact of a family history of alcoholism on the relationship between age at onset of alcohol use and DSM-IV alcohol dependence: results from the National Longitudinal Alcohol Epidemiologic Survey. Alcohol Health and Research World. 1998; 22:144-147. [PubMed: 15706789] 
Hardy PA, Chen W, Wilce PA. Chronic ethanol exposure and withdrawal influence NMDA receptor subunit and splice variant mRNA expression in the rat cerebral cortex. Brain Research. 1999; 819:33-39. [PubMed: 10082858]

Hicklin TR, Wu PH, Radcliffe RA, Freund RK, Goebel-Goody SM, Correa PR, Proctor WR, Lombroso PJ, Browning MD. Alcohol inhibition of the NMDA receptor function, long-term potentiation, and fear learning requires striatal-enriched protein tyrosine phosphatase. Proceedings of the National Academy of Sciences of the United States of America. 2011; 108:6650-6655. [PubMed: 21464302]

Hoffman PL, Rabe CS, Moses F, Tabakoff B. N-methyl-D-aspartate receptors and ethanol: inhibition of calcium flux and cyclic GMP production. Journal of Neurochemistry. 1989; 52:1937-1940. [PubMed: 2542453]

Holstein SE, Spanos M, Hodge CW. Adolescent C57BL/6J mice show elevated alcohol intake, but reduced taste aversion, as compared to adult mice: a potential behavioral mechanism for binge drinking. Alcoholism: Clinical and Experimental Research. 2011; 35:1842-1851.

Honse Y, Ren H, Lipsky RH, Peoples RW. Sites in the fourth membrane-associated domain regulate alcohol sensitivity of the NMDA receptor. Neuropharmacology. 2004; 46:647-654. [PubMed: 14996542]

Huttenlocher PR. Synapse elimination and plasticity in developing human cerebral cortex. American Journal of Mental Deficiency. 1984; 88:488-496. [PubMed: 6731486]

Insel TR, Miller LP, Gelhard RE. The ontogeny of excitatory amino acid receptors in rat forebrain--I. N-methyl-D-aspartate and quisqualate receptors. Neuroscience. 1990; 35:31-43. [PubMed: 1972786]

Kash TL, Matthews RT, Winder DG. Alcohol inhibits NR2B-containing NMDA receptors in the ventral bed nucleus of the stria terminalis. Neuropsychopharmacology. 2008; 33:1379-1390. [PubMed: 17625498]

Laurie DJ, Wisden W, Seeburg PH. The distribution of thirteen GABAA receptor subunit mRNAs in the rat brain. III. Embryonic and postnatal development. The Journal of Neuroscience. 1992; 12:4151-4172. [PubMed: 1331359]

Leri F, Flores J, Rodaros D, Stewart J. Blockade of stress-induced but not cocaine-induced reinstatement by infusion of noradrenergic antagonists into the bed nucleus of the stria terminalis or the central nucleus of the amygdala. The Journal of Neuroscience. 2002; 22:5713-5718. [PubMed: 12097523]

Li Q, Wilson WA, Swartzwelder HS. Differential effect of ethanol on NMDA EPSCs in pyramidal cells in the posterior cingulate cortex of juvenile and adult rats. Journal of Neurophysiology. 2002; 87:705-711. [PubMed: 11826039]

Li Q, Wilson WA, Swartzwelder HS. Developmental differences in the sensitivity of hippocampal GABAA receptor-mediated IPSCS to ethanol. Alcoholism: Clinical and Experimental Research. 2003; 27:2017-2022.

Li Q, Wilson WA, Swartzwelder HS. Developmental differences in the sensitivity of spontaneous and miniature IPSCs to ethanol. Alcoholism: Clinical and Experimental Research. 2006; 30:119-126.

Little PJ, Kuhn CM, Wilson WA, Swartzwelder HS. Differential effects of ethanol in adolescent and adult rats. Alcoholism: Clinical and Experimental Research. 1996; 20:1346-1351.

Lopez de Armentia M, Sah P. Development and subunit composition of synaptic NMDA receptors in the amygdala: NR2B synapses in the adult central amygdala. The Journal of Neuroscience. 2003; 23:6876-6883. [PubMed: 12890782]

Lovinger DM, White G, Weight FF. Ethanol inhibits NMDA-activated ion current in hippocampal neurons. Science. 1989; 243:1721-1724. [PubMed: 2467382]

Maldve RE, Zhang TA, Ferrani-Kile K, Schreiber SS, Lippmann MJ, Snyder GL, Fienberg AA, Leslie SW, Gonzales RA, Morrisett RA. DARPP-32 and regulation of the ethanol sensitivity of NMDA receptors in the nucleus accumbens. Nature Neuroscience. 2002; 5:641-648.

Markwiese BJ, Acheson SK, Levin ED, Wilson WA, Swartzwelder HS. Differential effects of ethanol on memory in adolescent and adult rats. Alcoholism: Clinical and Experimental Research. 1998; 22:416-421. 
Moy SS, Duncan GE, Knapp DJ, Breese GR. Sensitivity to ethanol across development in rats: comparison to [3H]zolpidem binding. Alcoholism: Clinical and Experimental Research. 1998; 22:1485-1492.

Pyapali GK, Turner DA, Wilson WA, Swartzwelder HS. Age and dose-dependent effects of ethanol on the induction of hippocampal long-term potentiation. Alcohol. 1999; 19:107-111. [PubMed: 10548153]

Quinlan EM, Olstein DH, Bear MF. Bidirectional, experience-dependent regulation of N-methyl-Daspartate receptor subunit composition in the rat visual cortex during postnatal development. Proceedings of the National Academy of Sciences of the United States of America. 1999; 96:12876-12880. [PubMed: 10536016]

Ren H, Honse Y, Peoples RW. A site of alcohol action in the fourth membrane-associated domain of the N-methyl-D-aspartate receptor. The Journal of Biological Chemistry. 2003; 278:48815-48820. [PubMed: 14506267]

Ren H, Salous AK, Paul JM, Lipsky RH, Peoples RW. Mutations at F637 in the NMDA receptor NR2A subunit M3 domain influence agonist potency, ion channel gating and alcohol action. British Journal of Pharmacology. 2007; 151:749-757. [PubMed: 17519952]

Roberto M, Madamba SG, Stouffer DG, Parsons LH, Siggins GR. Increased GABA release in the central amygdala of ethanol-dependent rats. The Journal of Neuroscience. 2004; 24:10159-10166. [PubMed: 15537886]

Rohde P, Lewinsohn PM, Seeley JR. Psychiatric comorbidity with problematic alcohol use in high school students. Journal of the American Academy of Child and Adolescent Psychiatry. 1996; 35:101-109. [PubMed: 8567601]

Ronald KM, Mirshahi T, Woodward JJ. Ethanol inhibition of N-methyl-D-aspartate receptors is reduced by site-directed mutagenesis of a transmembrane domain phenylalanine residue. The Journal of Biological Chemistry. 2001; 276:44729-44735. [PubMed: 11572853]

Schramm-Sapyta NL, DiFeliceantonio AG, Foscue E, Glowacz S, Haseeb N, Wang N, Zhou C, Kuhn $\mathrm{CM}$. Aversive effects of ethanol in adolescent versus adult rats: potential causes and implication for future drinking. Alcoholism: Clinical and Experimental Research. 2010; 34:2061-2069.

Sheng M, Cummings J, Roldan LA, Jan YN, Jan LY. Changing subunit composition of heteromeric NMDA receptors during development of rat cortex. Nature. 1994; 368:144-147. [PubMed: 8139656]

Silveri MM, Spear LP. Decreased sensitivity to the hypnotic effects of ethanol early in ontogeny. Alcoholism: Clinical and Experimental Research. 1998; 22:670-676.

Silveri MM, Spear LP. Ontogeny of ethanol elimination and ethanol-induced hypothermia. Alcohol. 2000; 20:45-53. [PubMed: 10680716]

Smothers CT, Woodward JJ. Effects of amino acid substitutions in transmembrane domains of the NR1 subunit on the ethanol inhibition of recombinant N-methyl-D-aspartate receptors. Alcoholism: Clinical and Experimental Research. 2006; 30:523-530.

Sobczyk A, Scheuss V, Svoboda K. NMDA receptor subunit-dependent $[\mathrm{Ca} 2+]$ signaling in individual hippocampal dendritic spines. The Journal of Neuroscience. 2005; 25:6037-6046. [PubMed: 15987933]

Suvarna N, Borgland SL, Wang J, Phamluong K, Auberson YP, Bonci A, Ron D. Ethanol alters trafficking and functional N-methyl-D-aspartate receptor NR2 subunit ratio via H-Ras. The Journal of Biological Chemistry. 2005; 280:31450-31459. [PubMed: 16009711]

Swartzwelder HS, Wilson WA, Tayyeb MI. Age-dependent inhibition of long-term potentiation by ethanol in immature versus mature hippocampus. Alcoholism: Clinical and Experimental Research. 1995a; 19:1480-1485.

Swartzwelder HS, Wilson WA, Tayyeb MI. Differential sensitivity of NMDA receptor-mediated synaptic potentials to ethanol in immature versus mature hippocampus. Alcoholism: Clinical and Experimental Research. 1995b; 19:320-323.

Varlinskaya EI, Spear LP. Acute effects of ethanol on social behavior of adolescent and adult rats: role of familiarity of the test situation. Alcoholism: Clinical and Experimental Research. 2002; 26:1502-1511. 
Varlinskaya EI, Spear LP. Differences in the social consequences of ethanol emerge during the course of adolescence in rats: social facilitation, social inhibition, and anxiolysis. Development Psychobiology. 2006; 48:146-161.

Wang J, Fang Q, Liu Z, Lu L. Region-specific effects of brain corticotropin-releasing factor receptor type 1 blockade on footshock-stress- or drug-priming-induced reinstatement of morphine conditioned place preference in rats. Psychopharmacology (Berl). 2006; 185:19-28. [PubMed: 16374599]

Weitlauf C, Egli RE, Grueter BA, Winder DG. High-frequency stimulation induces ethanol-sensitive long-term potentiation at glutamatergic synapses in the dorsolateral bed nucleus of the stria terminalis. The Journal of Neuroscience. 2004; 24:5741-5747. [PubMed: 15215296]

White AM, Bae JG, Truesdale MC, Ahmad S, Wilson WA, Swartzwelder HS. Chronic-intermittent ethanol exposure during adolescence prevents normal developmental changes in sensitivity to ethanol-induced motor impairments. Alcoholism: Clinical and Experimental Research. 2002; 26:960-968.

Williams K, Russell SL, Shen YM, Molinoff PB. Developmental switch in the expression of NMDA receptors occurs in vivo and in vitro. Neuron. 1993; 10:267-278. [PubMed: 8439412]

Wills TA, Klug JR, Silberman Y, Baucum AJ, Weitlauf C, Colbran RJ, Delpire E, Winder DG. GluN2B subunit deletion reveals key role in acute and chronic ethanol sensitivity of glutamate synapses in bed nucleus of the stria terminalis. Proceedings of the National Academy of Sciences of the United States of America. 2012; 109:E278-E287. [PubMed: 22219357]

Xia Y, Haddad GG. Ontogeny and distribution of GABAA receptors in rat brainstem and rostral brain regions. Neuroscience. 1992; 49:973-989. [PubMed: 1331860]

Yaka R, Phamluong K, Ron D. Scaffolding of Fyn kinase to the NMDA receptor determines brain region sensitivity to ethanol. The Journal of Neuroscience. 2003a; 23:3623-3632. [PubMed: 12736333]

Yaka R, Tang KC, Camarini R, Janak PH, Ron D. Fyn kinase and NR2B-containing NMDA receptors regulate acute ethanol sensitivity but not ethanol intake or conditioned reward. Alcoholism: Clinical and Experimental Research. 2003b; 27:1736-1742.

Yan H, Li Q, Madison R, Wilson WA, Swartzwelder HS. Differential sensitivity of hippocampal interneurons to ethanol in adolescent and adult rats. The Journal of Pharmacology and Experimental Therapeutics. 2010; 335:51-60. [PubMed: 20660126]

Yashiro K, Philpot BD. Regulation of NMDA receptor subunit expression and its implications for LTD, LTP, and metaplasticity. Neuropharmacology. 2008; 55:1081-1094. [PubMed: 18755202]

Yu ZY, Wang W, Fritschy JM, Witte OW, Redecker C. Changes in neocortical and hippocampal GABAA receptor subunit distribution during brain maturation and aging. Brain Research. 2006; 1099:73-81. [PubMed: 16781682]

Zecevic N, Bourgeois JP, Rakic P. Changes in synaptic density in motor cortex of rhesus monkey during fetal and postnatal life. Brain Research. Developmental Brain Research. 1989; 50:11-32. [PubMed: 2582602] 
A
B

\section{4 week old}

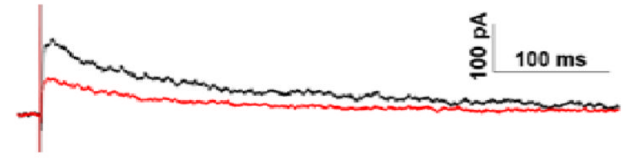

8 week old

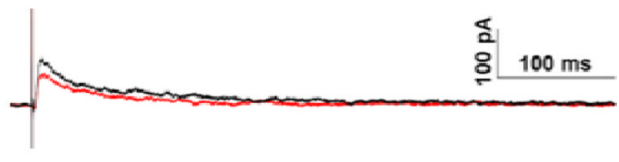

C

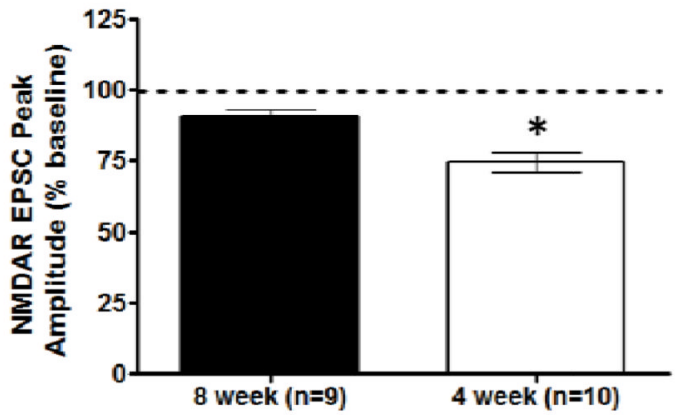

E

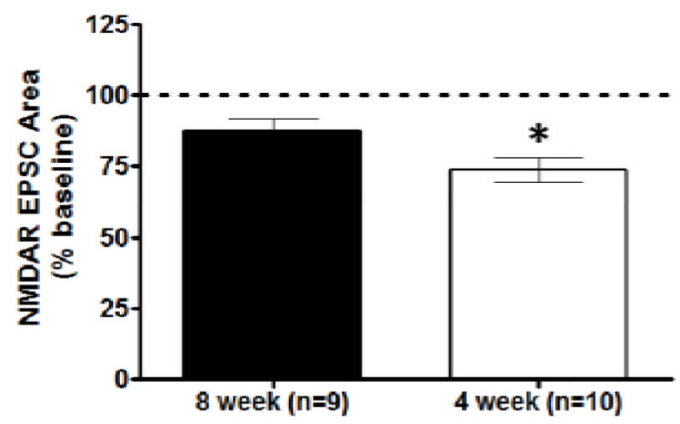

Figure 1. Effects of Acute Ethanol on NMDAR transmission in the BNST

Acute ethanol (50 $\left.\mathrm{m}_{\mathrm{m}} ; 10 \mathrm{~min}\right)$ was applied to vBNST slices from 4- and 8-week-old C57BL/6J mice; evoked NMDA-receptor isolated EPSCs were then recorded. A) Time course of NMDAR-EPSC peak amplitude in 4- and 8-week-old mice. B) Representative traces of NMDAR-EPSCs before (black trace) and after (red trace) removal of ethanol in 4and 8-week-old mice. C) Averaged peak amplitude of NMDAR-EPSC for the first $5 \mathrm{~min}$ after ethanol exposure in 4- and 8-week-old mice. D) Time course of NMDAREPSC area in 4- and 8-week-old mice. E) Averaged area of NMDAR-EPSC for the first 5 min after ethanol exposure in 4 - and 8-week-old mice. ${ }^{*} p<0.05$ 
A

B
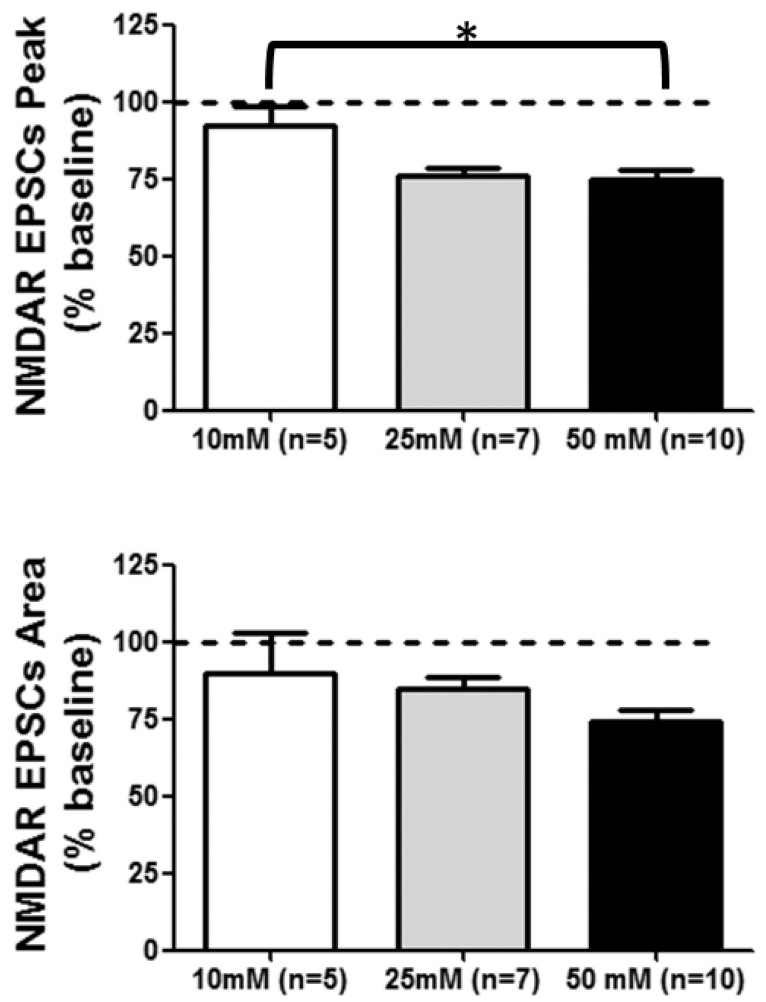

Figure 2. Dose Response of Acute Ethanol on NMDAR transmission in 4-week-old mice Acute ethanol $(10,25$, or $50 \mathrm{~m}$; $10 \mathrm{~min})$ was applied to vBNST slices from 4-week-old C57BL/6J mice; evoked NMDA receptor isolated EPCSs were then recorded. A) Representative time course of $10 \mathrm{~m}_{\mathrm{m}}$ ethanol exposure on NMDAR-EPSC peak and area. B) Averaged peak amplitude of NMDAR-EPSC for the first 5 min after ethanol exposure in 4week-old mice for each concentration. C) Averaged area of NMDAR-EPSC for the first 5 min after ethanol exposure in 4 -week-old mice for each concentration. ${ }^{*} p<0.05$ 
A

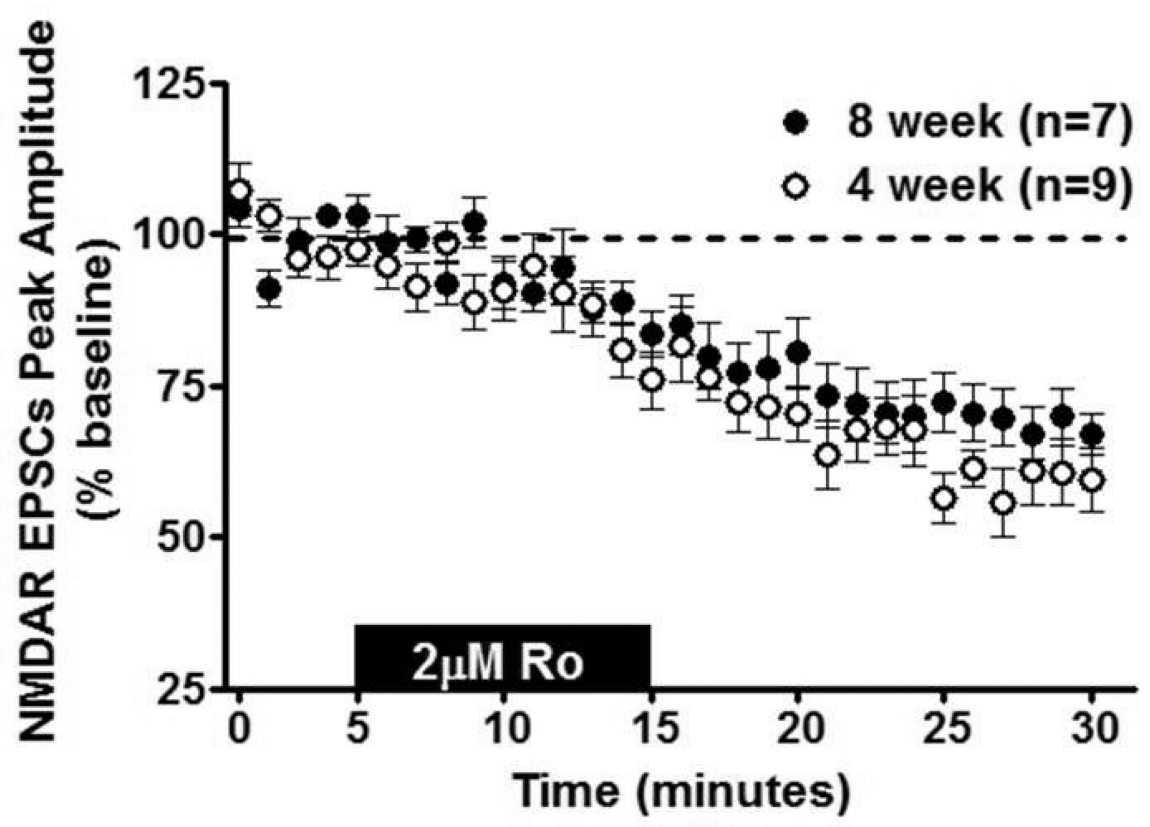

B

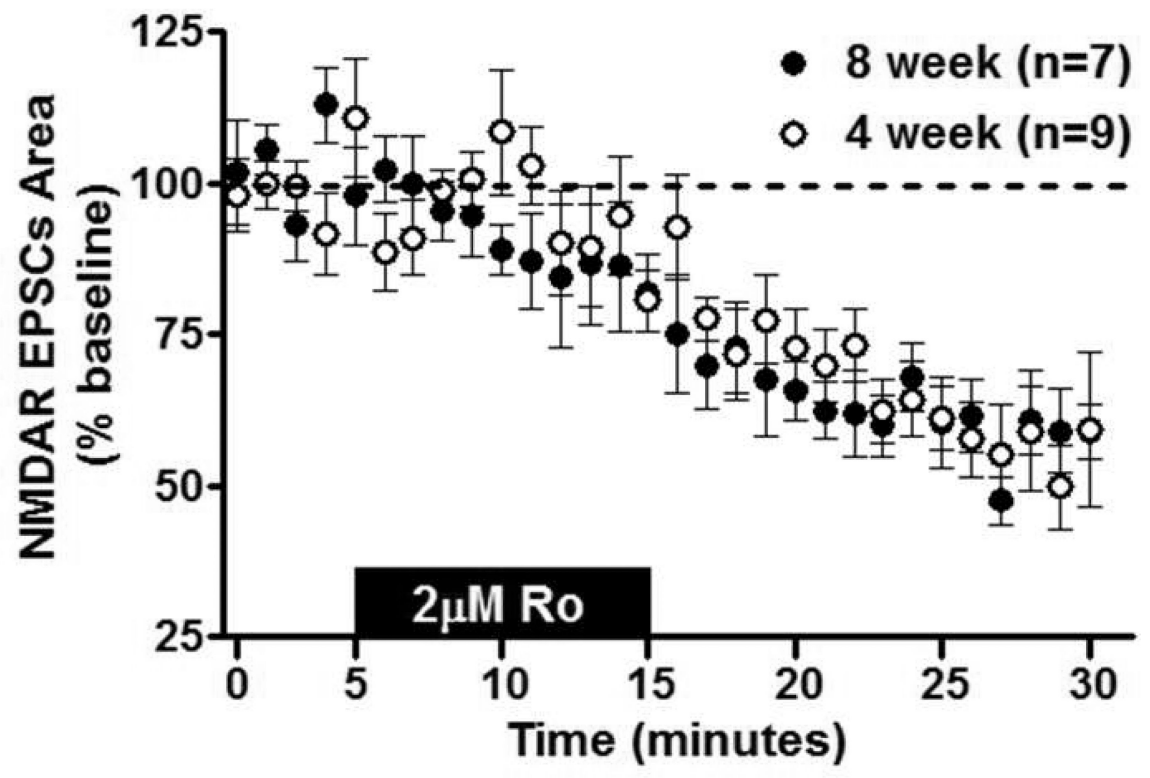

Figure 3. Effects of GluN2B Antagonist on NMDAR transmission in the BNST

Ro25-6981 ( $2 \mu \mathrm{M} ; 10 \mathrm{~min})$ was applied to vBNST slices from 4- and 8-week-old C57BL/6J mice; evoked NMDA-receptor isolated EPSCs were then recorded. A) Time course of NMDAR-EPSC peak amplitude in 4- and 8-week-old mice. B) Time course of NMDAREPSC area in 4- and 8-week-old mice. 
A

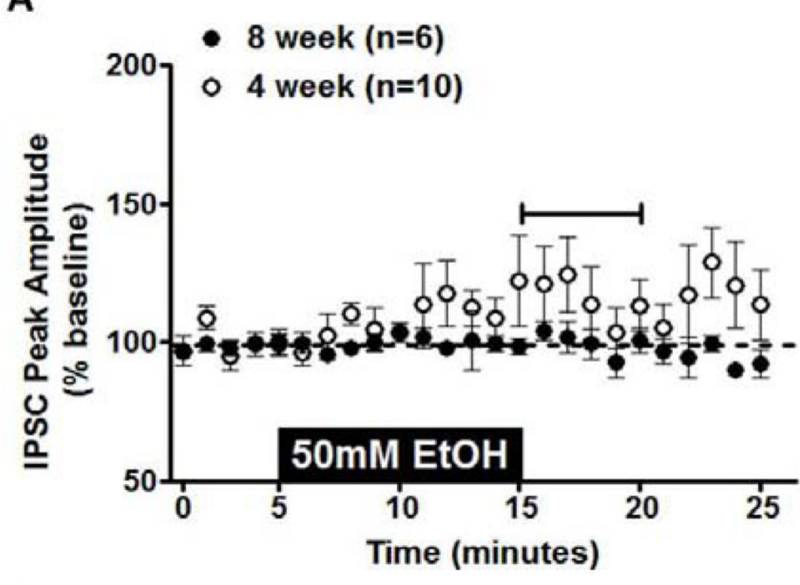

D

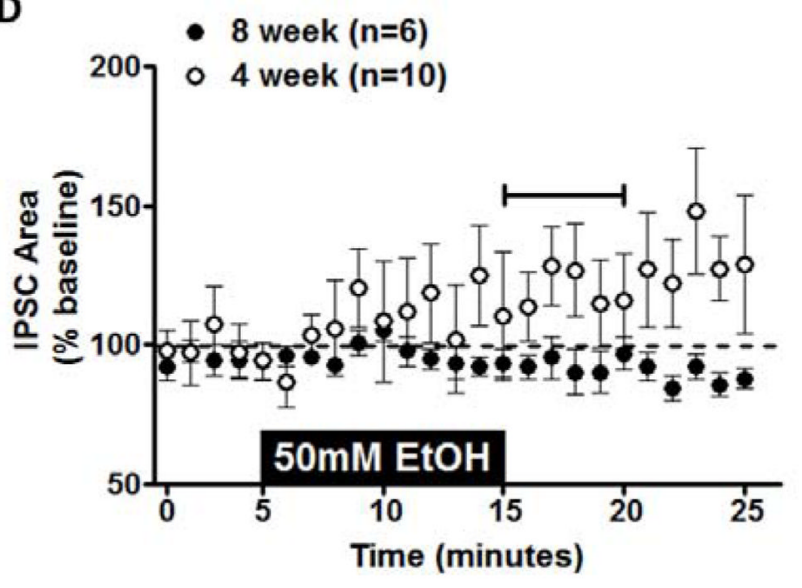

B
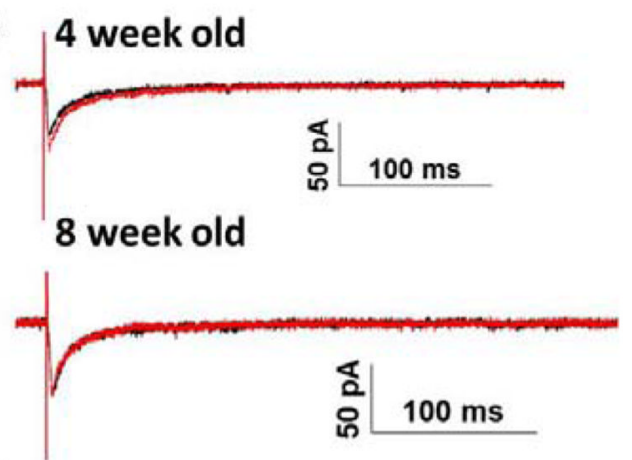

C

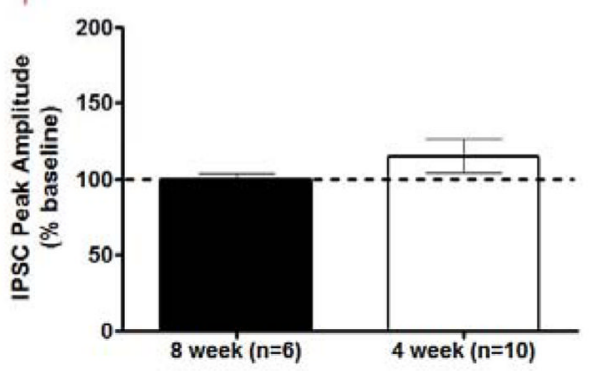

E

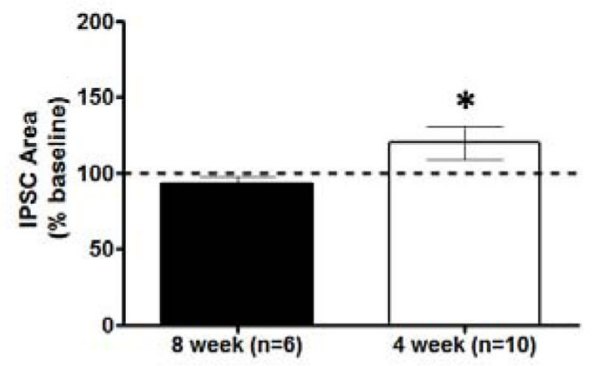

Figure 4. Effects of Acute Ethanol on GABAergic transmission in the BNST

Acute ethanol (50 $\mathrm{m}$; $10 \mathrm{~min}$ ) was applied to vBNST slices from 4- and 8-week-old C57BL/6J mice; evoked IPSCs were then recorded. A) Time course of IPSCs peak amplitude in 4- and 8-week-old mice. B) Representative traces of IPSCs before (black trace) and after (red trace) removal of ethanol in 4- and 8-week-old mice. C) Averaged peak amplitude of IPSCs for the first $5 \mathrm{~min}$ after ethanol exposure in 4- and 8-week-old mice. D) Time course of IPSCs area in 4- and 8-week-old mice. E) Averaged area of IPSCs for the first 5 min after ethanol exposure in 4- and 8-week-old mice. ${ }^{*} p<0.05$. Horizontal bars in A and $\mathrm{D}$ indicate time over which the ethanol effect was calculated. 